\title{
Synthesis of Cinnamic Acid Derivatives
}

\section{Lei Zhao, Yuanbiao Tu and Yuping Guo ${ }^{a^{*}}$}

School of Pharmacy, Jiangxi Science \& Technology Normal University, Nanchang 330013, China

*a305560258@qq.com

*The corresponding author

\section{Keywords: Cinnamic derivatives, Synthesis, Optimization}

\begin{abstract}
Quinazoline derivatives have been shown to be biologically active such as afatinib. The cinnamic acid derivative is an important part of the quinazoline derivative which exerts its activity. And Cinnamic acid derivatives were prepared by the benzaldehyde derivatives and malonic acids. In this paper, four cinnamic acid derivatives were prepared. The structure was confirmed by MS and ${ }^{1} \mathrm{H}$ NMR. In addition, this method not only saved the reaction time, but also improved the purity of the product. The yield of the step was about $90 \%$.
\end{abstract}

\section{Introduction}

In a number of studies, it has been found that some viral transfer gene expression products have tyrosine kinase (PTK) activity [1]. Therefore, PTK has become an important breakthrough in studying the mechanism of oncogenes and exploring the treatment of tumor diseases. Among them, the more important subfamilies are the epidermal growth factor receptor (EGFR) family [2]. Abnormal expression of epidermal growth factor in cancer cells is an important target for tumor therapy. Studies have shown that EGFR inhibitors are quinazoline structures [3].

Quinazoline derivatives are wildly found in many natural alkaloids, it is a kind of heterocyclic compound bearing important biological activity such as $\mathrm{N}$-(3-bromophenyl)-1H-imidazo[4,5-g]quinazolin-8-amine (2) [4], afatinib (3) [5], (R,E)-N-(4-((3-chloro-4-fluorophenyl)amino)-7-((tetrahydrofuran-3-yl)oxy)quinazolin-6-yl)-3-(2,3, 4-trimethoxyphenyl)acrylamide (4) [6]. These compounds have a very good antibacterial, anticancer, antispasmodic, malaria and anti-inflammatory effect, so they have an extremely important application prospect in biology, medicine and pesticide [7-9]. In a word, quinoline is a dominant skeleton structure, as a supporting structure, connecting different properties of the pharmacological groups, with a variety of biological macromolecules, resulting in a variety of biological activity, especially in the field of anti-tumor drug research, quinoline Class played an important role [9]. In addition, as early as 2000, Lamazz [11] synthesized benzimidazole and quinoline compounds on human HT-29 cell inhibitory activity reached a level of micro-mol.

The cinnamic acid derivative is an important part of the quinazoline derivative which exerts its activity. There are many synthetic methods of cinnamic acid derivatives have been reported, but most of the synthetic methods there are still deficiencies. In this paper, the synthetic methods of cinnamic acid derivatives were summarized and optimized. We prepared four kinds of cinnamic derivatives making it more suitable for industrial production. The structures of representative cinnamic derivatives were shown in Fig. 1. 

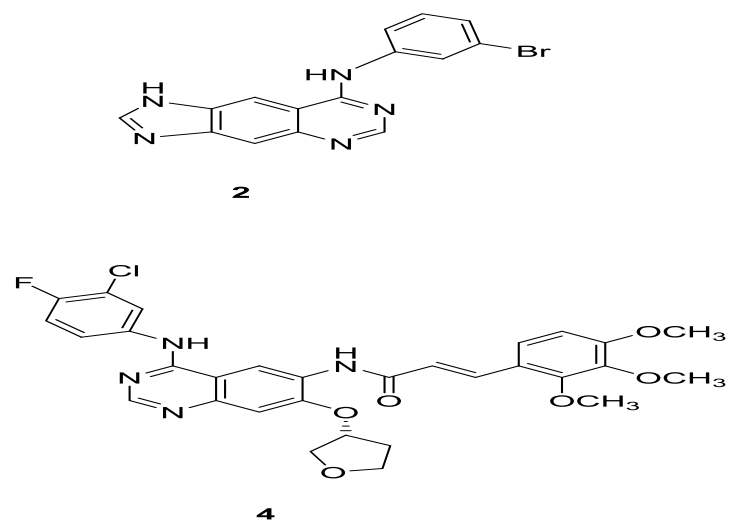

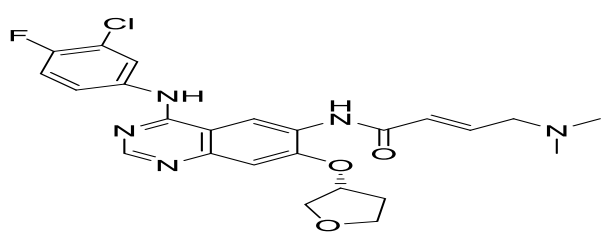

3

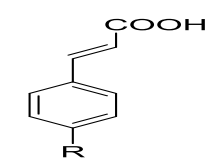

The target compounds

Figure 1. Structure of representative cinnamic derivatives

\section{Materials and Methods}

NMR spectra were performed using Bruker $400 \mathrm{MHz}$ spectrometers (Bruker Bioscience, Billerica, MA, USA) with TMS as an internal standard. Mass spectra (MS) were taken in ESI mode on Agilent 1100 LC-MS (Agilent, Palo Alto, CA, USA). All the materials were obtained from commercial suppliers and used without purification, unless otherwise specified. Yields were not optimized. TLC analysis was carried out on silica gel plates GF254 (Qindao Haiyang Chemical, China).

\section{Synthesis of Compounds}

The structures and the synthetic route were shown in Scheme 1.<smiles>[R]c1ccc(C=O)cc1</smiles>

5<smiles>[R]c1ccc(/C=C/C(=O)O)cc1</smiles>

1

$$
\begin{aligned}
& \text { 1a: } \mathrm{R}=\mathrm{OCH}_{3} \\
& \text { 1b: } \mathrm{R}=\mathrm{Br} \\
& \text { 1c: } \mathrm{R}=\mathrm{F} \\
& \text { 1d: } \mathrm{R}=\mathrm{OH}
\end{aligned}
$$

Scheme 1 . The synthetic route of compound 1a-1d

Reagents and conditions: malonic acid; pyridine; piperidine; $110^{\circ} \mathrm{C} ; 1.5 \mathrm{~h}$

\section{(E)-3-(4-methoxyphenyl) acrylic acid (1a)}

To a $25 \mathrm{ml}$ round bottom flask was added p-bromobenzaldehyde $(0.50 \mathrm{~g}, 3.72 \mathrm{mmol})$, pyridine $(6.0 \mathrm{ml}), 2$ drops of piperidine and malonic acid $(0.38 \mathrm{~g}, 3.68 \mathrm{mmol})$. The above round bottom flask was placed in an oil bath and reacted at $110^{\circ} \mathrm{C}$ for $1.5 \mathrm{~h}$. Next, the reaction was complete by TLC analysis. Dilute hydrochloric acid to adjust the $\mathrm{pH}$ to 5 , filtration, washing with water to get the product. (0.45 g, 90.0\%) ESI -MS m/z: $179.0[\mathrm{M}+\mathrm{H}]+$ +. 1H NMR (400 MHz, DMSO) $\delta 12.25$ (s, $1 \mathrm{H}), 7.64(\mathrm{~d}, \mathrm{~J}=5.3 \mathrm{~Hz}, 1 \mathrm{H}), 7.63(\mathrm{~s}, 1 \mathrm{H}), 7.54(\mathrm{~d}, \mathrm{~J}=16.0 \mathrm{~Hz}, 1 \mathrm{H}), 6.98(\mathrm{~s}, 1 \mathrm{H}), 6.95(\mathrm{~s}, 1 \mathrm{H}), 6.38$ $(\mathrm{d}, \mathrm{J}=16.0 \mathrm{~Hz}, 1 \mathrm{H}), 3.79$ (s, 3H).

\section{(E)-3-(4-bromophenyl) acrylic acid (1b)}

The experimental procedure was the same as for compound 1a. $(0.43 \mathrm{~g}, 86.0 \%)$ ESI $-\mathrm{MS} \mathrm{m} / \mathrm{z}$ : $228.0[\mathrm{M}+\mathrm{H}]+.1 \mathrm{H}$ NMR $(400 \mathrm{MHz}, \mathrm{DMSO}) \delta 12.50(\mathrm{~s}, 1 \mathrm{H}), 7.67(\mathrm{~s}, 1 \mathrm{H}), 7.65(\mathrm{~s}, 1 \mathrm{H}), 7.62(\mathrm{~s}$, $1 \mathrm{H}), 7.59(\mathrm{~d}, \mathrm{~J}=5.7 \mathrm{~Hz}, 1 \mathrm{H}), 7.54(\mathrm{~s}, 1 \mathrm{H})$. 


\section{(E)-3-(4-fluorophenyl) acrylic acid (1c)}

The experimental procedure was the same as for compound 1a. $(0.44 \mathrm{~g}, 88.5 \%)$ ESI $-\mathrm{MS} \mathrm{m} / \mathrm{z}$ : $167.1[\mathrm{M}+\mathrm{H}]+.1 \mathrm{H}$ NMR (400 MHz, DMSO) $\delta 12.44(\mathrm{~s}, 1 \mathrm{H}), 7.77(\mathrm{dd}, \mathrm{J}=8.1,5.9 \mathrm{~Hz}, 1 \mathrm{H}), 7.59$ $(\mathrm{d}, \mathrm{J}=16.1 \mathrm{~Hz}, 1 \mathrm{H}), 7.25(\mathrm{t}, \mathrm{J}=8.7 \mathrm{~Hz}, 1 \mathrm{H}), 6.52(\mathrm{~s}, 1 \mathrm{H}), 6.48(\mathrm{~s}, 1 \mathrm{H})$.

\section{(E)-3-(4-hydroxyphenyl) acrylic acid (1d)}

The experimental procedure was the same as for compound 1a. $(0.45 \mathrm{~g}, 89.3 \%)$ ESI -MS m/z: $165.1[\mathrm{M}+\mathrm{H}]+.1 \mathrm{H}$ NMR $(400 \mathrm{MHz}, \mathrm{DMSO}) \delta 12.16(\mathrm{~s}, 1 \mathrm{H}), 9.98(\mathrm{~s}, 1 \mathrm{H}), 7.52(\mathrm{~s}, 1 \mathrm{H}), 7.51(\mathrm{~s}$, $1 \mathrm{H}), 7.50(\mathrm{~s}, 1 \mathrm{H}), 7.47(\mathrm{~s}, 1 \mathrm{H}), 6.78(\mathrm{~d}, \mathrm{~J}=8.3 \mathrm{~Hz}, 2 \mathrm{H}), 6.28(\mathrm{~d}, \mathrm{~J}=15.9 \mathrm{~Hz}, 1 \mathrm{H})$.

\section{Conclusions}

In summary, four cinnamic acid derivatives were prepared by the reaction of substituted benzaldehydes and malonic acid. The synthesis method and reaction conditions of cinnamic acid dervatives were optimized. The purity of the product was higher than before and it was more suitable for industrial production. Its structure was confirmed by MS and 1H NMR spectrum.

\section{Acknowledgments}

We gratefully acknowledge the generous support provided by Science and Technology Project Founded by the Education Department of Jiangxi Province (No. GJJ150813).

\section{References}

[1] Shelver W L, Smith D J, Berry E S. Production and characterization of a monoclonal antibody against the $\beta$-adrenergic agonist ractopamine $[\mathrm{J}]$. Journal of agricultural and food chemistry, 2000, 48(9): 4020-4026.

[2] Kim Y J, Cho Y A, Lee H S, et al. Investigation of the effect of hapten heterology on immunoassay sensitivity and development of an enzyme-linked immunosorbent assay for the organophosphorus insecticide fenthion[J]. Analytica Chimica Acta, 2003, 494(1): 29-40.

[3] Shin D M, Donato N J, Perez-Soler R, et al. Epidermal growth factor receptor-targeted therapy with $\mathrm{C} 225$ and cisplatin in patients with head and neck cancer [J]. Clinical Cancer Research, 2001, 7(5): 1204-1213.

[4] Wright S W, Hageman D L, McClure L D, et al. Allosteric inhibition of fructose-1, 6-bisphosphatase by anilinoquinazolines[J]. Bioorganic \& medicinal chemistry letters, 2001, 11(1): 17-21.

[5] Suda K, Murakami I, Katayama T, et al. Reciprocal and complementary role of MET amplification and EGFR T790M mutation in acquired resistance to kinase inhibitors in lung cancer [J]. Clinical cancer research, 2010, 16(22): 5489-5498.

[6] Tu Y, OuYang Y, Xu S, et al. Design, synthesis, and docking studies of afatinib analogs bearing cinnamamide moiety as potent EGFR inhibitors[J]. Bioorganic \& medicinal chemistry, 2016, 24(7): 1495-1503.

[7] Cao S L, Feng Y P, Jiang Y Y, et al. Synthesis and in vitro antitumor activity of 4 $(3 \mathrm{H})$-quinazolinone derivatives with dithiocarbamate side chains[J]. Bioorganic \& medicinal chemistry letters, 2005, 15(7): 1915-1917.

[8] Kornet M J, Varia T, Beaven W. Synthesis and anticonvulsant activity of 3-amino-4 (3H)-quinazolinones[J]. Journal of heterocyclic chemistry, 1983, 20(6): 1553-1555.

[9] Bahadur S. Syntheses and Biological Activities of Some New 4 (3H)-Quinazolinones[J]. Archiv der Pharmazie, 1983, 316(11): 964-968. 
[10]Beria I, Ballinari D, Bertrand J A, et al. Identification of 4, 5-dihydro-1 H-pyrazolo [4, 3-H] quinazoline derivatives as a new class of orally and selective polo-like kinase 1 inhibitors [J]. Journal of medicinal chemistry, 2010, 53(9): 3532-3551.

[11]Lamazzi C, Léonce S, Pfeiffer B, et al. Expeditious synthesis and cytotoxic activity of new cyanoindolo [3,2-c] quinolines and benzimidazo [1, 2-c] quinazolines[J]. Bioorganic \& medicinal chemistry letters, 2000, 10(19): 2183-2185. 